\title{
Embedding Design Thinking Paradigm in a University's Business Assistance to Small Business
}

\author{
Afred Suci $^{1,2} \cdot$ Sri Maryanti ${ }^{2}$ (D) Hardi Hardi ${ }^{2} \cdot$ Nining Sudiar $^{2}$
}

Accepted: 12 March 2021 / Published online: 4 April 2021

(C) The Author(s), under exclusive licence to Springer Science+Business Media, LLC, part of Springer Nature 2021

\begin{abstract}
Interest gaps exist between the university and the small firms when running a business assistance program, leading to the importance of practical guidance that could accommodate both partners' interests. However, there is relatively little literature about how the university team should implement business assistance to a small partnering firm. Accordingly, this research used three stages and a mixed-method approach to solve the problem, involving qualitative and quantitative techniques and action research. This study introduced PROSEM, an acronym for problem rooting, solution treatment, and measurement, to guide university business assistance to small firms by adopting the design thinking paradigm. The results revealed a significant impact on the SME's business performance. The PROSEM process further proved that a measurable and well-planned treatment based on the root causes could increase revenue and production volume and reduce the returned product rate. At the same time, this study enriches researchers' knowledge and skills in developing the concept and guidelines of a systematic problem-solving method using unique, real cases in the small business community. As such, the PROSEM affirms that design thinking is an open and adjustable concept which can be embedded and modified in various problemsolving procedures.
\end{abstract}

Keywords Business assistance $\cdot$ Higher education institutions $\cdot$ Small medium enterprises Design thinking

\section{Introduction}

"They only came a few times, providing short counseling, a little capital assistance, and never to be seen again" is a common innuendo uttered by small- and medium-sized enterprises (SMEs) after an engagement with a higher education institution (HEI) community service. The project motivation is often driven by the HEI's needs rather than the SMEs' needs (Noor 2010). Many SMEs often perceive the HEI's assistance as being irrelevant or inappropriate to what they really need (Johnson and Tilley 1999). While an HEIs' mission

Sri Maryanti

sri_maryanti@unilak.ac.id

1 National Taiwan University of Science and Technology, Taipei, Taiwan

2 Universitas Lancang Kuning, Pekanbaru, Indonesia 
is to develop reliable and useful knowledge, the SMEs seek to capitalize on existing knowledge to obtain a competitive advantage (Bjursell and Engstrom 2017). Therefore, HEIs need to offer their goods and services carefully so that SMEs can relate to and comprehend, emphasizing the added value for SMEs.

Both Gibb (2000) and Rezk and Gamal (2020) point out some common approaches HEIs use when supporting SMEs: assistance, intervention, training, consultation, public awareness, and global community development. Salleh and Omar (2013) suggest five additional methods: knowledge exchange, research and development, training, consultation work, and product commercialization. Most studies discussed the effectiveness of practices that partially increase SME performance. For example, knowledge and technology transfer plays a critical role in university-industry collaboration (UIC) (e.g., Formica 2005; D'Este et al. 2019). Visitation, risk training and assessment, and business assistance methods effectively helped more than 700 small business operators in Australia (Breen and Seers 2002). Matt and Rauch (2013) improved the productivity of an Italian small business using a work layout redesign intervention. Ankrah and Al-Tabbaa (2015) suggest that training is one of the most useful methods in UIC activity. Furthermore, although finance intervention has a significant impact on SMEs' job creation, the greater impact came from the training and business development services intervention (Grimm and Paffhausen 2015).

Despite the effectiveness of these methods in the HEI-SME linkage context, a clear step-by-step of two or more integrated methods has not yet been discussed. Such a discussion is essential because the stereotypical problem facing HEIs when offering business assistance to SMEs is the lack of funding (Noor 2010; Puukka 2008). Hence, HEIs need a detailed plan to ensure their limited funds are effectively used and enhance the SMEs' performance. We believe that this goal can be achieved by deploying a proper procedure that combines well-constructed plans based on SMEs' interests, treatment plans and execution, and results measurement. Thus, this current study has one primary goal: to design an effective business assistance procedure from HEI to SME.

To achieve the main goal of this study, we adopted the design thinking (DT) approach, given that the common reasons for a failing HEI-SME linkage are due to the university misunderstanding of the SME's real needs, inconsistent mentoring programs, the inability to maintain the relationship once the initial program has been fulfilled, and the difficulty of measuring the results of the programs (e.g., Johnson and Tilley 1999; Breen and Seers 2002; Ferreira et al. 2010; Perkmann et al. 2011). Using DT to mitigate these problems requires holistic and systematic mentoring (Wade and Demb 2009) to provide long-term sustainable impacts (Temtime et al. 2004), initiated by exploring the SMEs' real needs, giving proper treatments and solutions, and evaluating by measuring the effects on the SMEs. Moreover, the DT approach has been widely used in several action studies in the context of educational and business-related problem solving and innovation quests (e.g., Liedtka 2011; Wetzler 2013; Selloni and Corubolo 2017; Che-Tu et al. 2018). Gonera and Pabst (2019) found that implementing DT in industry-academia relationships might provide successful innovations, superior solutions, and lower risks and change costs. Nevertheless, how to instill a DT paradigm in HEI business assistance for SMEs is still unclear.

The manuscript is structured as follows. In the next section, the authors present a literature review, aiming at outlining the issues of the HEI-SME business assistance and design thinking concept, as well as the gaps that have not been discussed by past relevant studies. Given the extensive context of this study's main goal, a practical example of a SME's real situation is needed. Hence, the next section presents the targeted research questions and hypotheses developed for one small Indonesian firm's actual business setting. The next section summarizes the research method, divided into three studies. The results, discussions, 
theoretical and practical contributions, limitations, and conclusions are then discussed accordingly.

\section{Literature Review}

\section{Research Dynamic of HEI-SME Business Assistance Programs}

SMEs are the most common form of enterprise in many countries (Boldrini et al. 2017; Tambunan 2008), occupying a dominant position in the worldwide business community. SMEs account for more than $90 \%$ of all firms, for example, in China and Indonesia (Ismail et al. 2011; Gordon et al. 2012; Hong and Lu 2016; Maryanti et al. 2020). Therefore, SMEs are crucial to regional and national economic development, mainly to generate new jobs and entrepreneurship (Thorpe et al. 2009; Jones et al. 2010; Rakićević et al. 2016). Despite all of the SMEs' advantages, it is a fact that most of them are fragile, and many SMEs go out of business within a few years of inception (Peña 2004).

SMEs encounter relatively similar business problems, such as finance, marketing, human resources, skill, technology, quality, and management (e.g., Ferreira et al. 2010; Fausiah 2016). The SMEs' failure rate is relatively high throughout the world (Fang et al. 2009). Approximately $40 \%$ of newly established SMEs fail to survive their first year, and $90 \%$ collapse within ten years of operation (Hong and Lu 2016). Even in developing economies like South Africa, the failure rate reaches $70 \%-80 \%$ in just a few years (Ferreira et al. 2010).

Due to the limitation of SMEs' resources, it is obvious that they need external support from stakeholders such as government bodies, corporations, and any other non-profit organization like HEIs in the form of both financial and non-financial supports. Financial support refers to financial aid from various organizations provided to SMEs to start new businesses or improve SMEs' business capacity. In contrast, non-financial aid offers training, mentoring, technology transfer, business incubators, business networking, and business assistance (Rakićević et al. 2016). In addition to money, integrating available knowledge and expertise can have a simultaneous impact on the SMEs' performance. The point is that all supports given to SMEs should encourage modernization, capacity building, and business scale expansion (Tambunan 2007).

To date, many studies have discussed various types of support available to SMEs. For example, Ferreira et al. (2010) found that support for product issues should begin even before starting a business, and then, when the business is in operation, the SME may need finance, marketing, and human resource support. Another study by Temtime et al. (2004) revealed that the primary supports needed by SMEs are finance, training, business clinics, and technology transfer. In particular, the most common forms of small firm support in Indonesia include training (22.9\%), capital assistance (17.3\%), facilities (16.1\%), and dissemination or the introduction of new technologies and methods (15.2\%) (Tambunan 2008). Meanwhile, in the context of the HEIs-SMEs relationship, knowledge and technology transfer are the critical method of collaboration (e.g., Formica 2005; D'Este et al. 2019). Nevertheless, not all external support types effectively improve SMEs' business performance. For example, Lambrecht and Pirnay (2005) found that private external consultancies had an insignificant effect on SMEs' net job creation, turnover, or financial matters. Furthermore, large variations in HEIs and SMEs' outcomes are revealed because each party has different missions, moves in distinct phases, and appreciates different values (Virani 2014; Bjursell and Engstrom 2017). 
The different results generated from various support types prove that no such method can be generalized to all SMEs' conditions. Each SME needs a different type of support because they may vary in business size, industry type, the form of ownership, development stages, leadership, sources of capital, and so forth (Temtime et al. 2004). The crucial question must be asked whether the support provided is relevant and whether it meets the SMEs' particular needs and problems (Ferreira et al. 2010). Past studies have apparently overlooked this question.

There is a potential mismatch between what is required by SMEs and what is given by the support providers (Storey 2002), especially the supports coming from HEIs. Many studies have demonstrated that university-industry collaborations are far from straightforward because most HEIs focus more on science-based projects and are not generally focused on the SMEs' needs and problems (Lövsund et al. 2020). That is why HEIs are rarely the first point of call for SMEs (Ismail et al. 2011). For example, less than $10 \%$ of SMEs in South Africa sought support from HEIs because what they offered was not useful in practice, did not meet the SMEs' needs and problems, or those academicians were not well suited to provide entrepreneurial support (Ferreira et al. 2010).

Consequently, an HEI's role and proper techniques for supporting SMEs are less well understood. Thus, there is a lack of guidelines for conducting appropriate and effective business assistance from HEIs to SMEs. Systematic and holistic business assistance is useful to create long-term sustainable development for SMEs (Temtime et al. 2004). As such, it is necessary to discuss how an HEI can deliver practical business assistance to SMEs. However, extensive past literature related to business assistance is mostly written from the perspective of survey method to assess or evaluate the programs that had already been delivered to numbers of SME (e.g., Breen and Seers 2002; Lewis et al. 2007; Mole et al. 2011; Hong and Lu 2016; Adham et al. 2019). In the meantime, there is a growing need to understand how business assistance should be designed systematically, starting from how to know what the SMEs really need, what kind of treatments should be offered, and how to measure the treatments' effectiveness. In this case, an action research (AR) approach could be the most appropriate method to fill this literature gap. The current study aimed to address this shortfall in the literature.

\section{Applying Design Thinking Approach in HEI-SME Business Assistance}

Some barriers exist in the HEI-SME interaction. The most fundamental drawback is problem identification. Different goal orientation and learning opportunities between HEIs and SMEs lead to different perspectives on how to see a real problem. Ironically, the biggest issue HEIs face when conducting business assistance is problem recognition (Maryanti et al. 2020). Misidentified problems could lead to the implementation of treatments or solutions that are less than ideal because problem identification is crucial when determining proper solutions (Payne and Wenger 1998). Another obstacle is measuring the project's result, which is a difficult stage of the HEI-SME collaboration process (Perkmann et al. 2011). To date, however, scant replicable examples are provided to know how the procedure of HEI-SME business assistance should be applied in research, leading to the importance of creating a systematic procedure and testing it in a real small business situation.

Within the last two decades, only a few scholars have implemented HEI's action-based procedures to mitigate SME problems. For example, Warren (2003) deployed business assistance called business process reengineering (BPR) to a small building and garden 
supply and manufacturing firm in the UK using a collaboration of UK-government and university support. That project was initiated by identifying the firm's problems: poor delegation, coordination, and control of activities, along with a need to increase business scale through production automation. The BPR project, which embraced the development of management and information systems to improve employees' and materials' monitoring and tracking, enhanced the employees' work culture and environment. At least three limitations could be observed in the article. First, the problem identification came solely from the firm managers; the author did not absorb the input from other stakeholders' perspectives, such as employees or customers/clients. It is possible that the core problems were not comprehensively understood. Second, the issue was limited mainly to human-resource-related issues. Third, the BPR implementation result was not measured and described quantitatively; hence, the readers might not be well assured about the effectiveness of the BPR intervention.

Another example from the UK context was Ismail et al. (2011). Assisting one small table manufacturer in the UK, they introduced the five-step intervention to mitigate the company's problems whose procedure included: (1) process audit and agreement of scopes and objectives; (2) work plan development; (3) implementation; (4) evaluation, and (5) indepth intervention. Again, the problem identification was derived merely from the firm's owner-manager, excluding the employees and customers/clients. The problems-or what they called turbulences - were broadly identified in the context of product, process, organization, people, and operations. To sum, the five-step procedure helped the firm to expand its market, develop the product line, reduce operating costs, and improve its profit margin. However, the article did not clearly explain how a particular intervention was planned, implied, and measured. For instance, what and how was the intervention used that caused the $11 \%$ reduction in material wastage, $8 \%$ reduction in rejects and returns, and the $70 \%$ reduction in late deliveries?

Matt and Rauch (2013) assisted a small bathroom furnishing firm in northern Italy. Instead of being driven by the firm's real existing problem analysis, their study was driven by the firm's desire to improve its production rate. The information came only from the management. Matt and Rauch then introduced the Lean production approach to help the company. Before initiating the process, the concept was decomposed into single working packages and planned on a two-year axis. The next step was elaborating a detailed realization plan (containing responsibilities and due dates) and then presenting the plan to all staff. In the operative stage, the further action was reorganizing the production layout and introducing work cells and small autonomous teams responsible for the quality of the process steps. This assistance method successfully achieved a better-organized production layout, which, in turn, increased the firm's productivity rate by $25 \%$. However, this technique's step-by-step procedure was not adequately described in the six-page article.

To achieve a clear, adaptable, and effective procedure for business assistance to SMEs, HEIs need to carefully and systematically plan the program, starting from recognizing the real problems and needs of the partnering SMEs before stepping forward to design treatment alternatives to each problem and closing the cycle of the assistance program with the results measurement. Similar to action research, the assistance program may require more than a single cycle (Davison et al. 2004) because dissatisfaction or mistarget might occur after the measurement phase; thus, the assistance procedure should possibly be rerun or modified. The cycle of business assistance can be well conducted using the design thinking (DT) paradigm, an approach considered by many researchers since Rowe (1987) used it in the book Design Thinking in 1987. 
Design thinking is a paradigm for dealing with business problems (Martin 2009). It has been widely used by the business and management community to broaden perspectives on challenges encountered by contemporary organizations (Stacey et al. 2000). Nevertheless, design thinking is rarely used in the HEI-SME business support model.

The basic equation of DT is What (thing) + How (working principle) $=$ Result (observed) (Dorst 2011). If this equation is embedded in SME assistance planning, the stages include: first, identifying and mapping the problems; second, applying treatment to the identified problems; and third, measuring the effectiveness of the treatment on business performance and taking learning experiences from the processes. The stages are also relevant to Susman and Evered's (1978) Canonical Action Research (CAR), one of the most popularly used methods in action research for social science. CAR suggests five stages in a cycle: diagnosing action planning action taking evaluating learning. The DT paradigm could be used closely and supportively with many kinds of action research. Over time, similar models have evolved, adjusting to specific areas, interests, or goals, such as Reflective System Development, ETHICS, Action Science, Soft System, and Action Learning (Davison et al. 2004). Each circumstance requires adaptable plans and techniques rather than adopting predetermined methods (Davison et al. 2004). A better impact could be obtained by SMEs that received customized support services (Rakićević et al. 2016). For these reasons, Calgren et al. (2016) call for more research on how design thinking concepts could be used in a project context such as the HEI-SME business assistance model.

\section{Introducing the PROSEM}

This study proposes PROSEM, inspired by the DT paradigm, CAR, and other existing models, to develop a practical guideline for HEI business assistance to SMEs. PROSEM consists of Problem Rooting $\rightarrow$ Solution $\rightarrow$ Treatment Measurement in one cycle of action research. We believe that the stages in a cycle could be simplified without losing their essence as long as the cycle can reflect them in subsequent activities. As such, PROSEM was further defined in this study as an integrated assistance concept conducted by an HEI to systematically and comprehensively support an SME, from the problem identification stage to determining solutions, and finally, measuring the effect of that support on business performance.

Problem Rooting Problem identification and the solutions developed are part of the problem-solving process, which refers to a cognitive operation searching for a solution to identify problems or find the path to reach a goal (Wang and Chiew 2010). The classic theory proposed by Polya (1954) showed the problem-solving procedure starts with understanding the problem, determining and executing the appropriate actions, and evaluating the plan's overall effectiveness. One method of recognizing the real issues encountered by a small firm is the root-cause analysis (RCA), which is a process of understanding the core of a problem. The RCA is a useful technique to help determine current obstacles and identify specific areas in which process improvements might produce the biggest benefit (Wilson et al. 1993). In addition, a mind map strategy may be employed to understand the root causes, followed by the implementation of the solutions. A mind map is a multi-colored and image-centered, radial diagram representing semantic or other connections between material. It shows the sub-topics of a domain creatively and seamlessly (Buzan 1995) and is often used for its simplicity (Eppler 2006). 
Solution Treatments The problem needs to be deconstructed (Hekkert and Van Dijk 2011) before referring to a specific solution. The solution can only start working effectively once the core of the problem situation has been established (Dorst 2011). Payne and Wenger (1998) identified two elements of problem-solving. First, understanding the problem and searching for the possible solution in the solver's experience. When a solver cannot find a solution to a particular issue, reasons might include the ambiguity of the problem or the unavailability of a solution (Wang and Chiew 2010). As such, the HEI team may not be able to rely on internal resources when providing business assistance to small firms; thus, they need to involve external resources, both financial and non-financial, such as expertise and new technology or methods. Effective integrated solutions may be obtained through collaboration. The first step toward gaining a high-value integrated solution is recognizing a firm's traditional area of strength or operation and then diversifying or improving into new productive and innovative activities (Davies 2004). Treatments should be provided following the conditions encountered. That is, a "firm-centric" solution should be given on a production issue, while a "customer-centric" treatment should be implemented when the identified problem concerns a market issue.

Measuring the Effectivity The evaluation step should begin by observing activities when starting the program. A process of evaluation should be initiated in the process stage that continues until the result. Program measurement can identify treatment types that need evaluation and determine whether the treatments achieve their objectives. If a treatment program has been implemented effectively, the measurement of the outcomes may focus on the evaluation. At this stage, according to Davison et al. (2004), the reflection or learning process occurs to decide whether or not to continue the program. According to Posavac (2016), program measurement can use different types of program evaluations, such as need-based, process-based, and outcome-based. A need-based assessment aims to identify and measure the level of unmet needs within the program. Process-based measurement involves checking the planned processes and activities. The outcome-based evaluation focuses on the results that are commonly quantified. The evaluation is not limited to measure the level of target achievement, but in a more challenging situation, the measurement also covers the comparison of pre-and post-program participation (Boruch 1997).

\section{Research Questions and Hypotheses}

A successful business assistance program requires supporting factors: intensiveness and sustainability (Wahyudi 2009). Intensiveness demands a close interaction between the service provider (HEI) and receiver (SME); thus, a local SME would be the most effective choice for HEI to guarantee closeness and intensive interaction in the process. Sustainability demands user-driven and continuous programs provided by HEI to the assisted SME. At the same time, the SME's problem may be too complex to be handled by a single HEI. Financial and human resources are the most critical problems for an HEI when conducting SME business assistance. A study involving action research is a highly involved method, demands good backup support, and can be costly (McGrath and O'Toole 2012). For these reasons, this study needs to determine one geographically close industry with the potential for local economic development. Hence, a small, traditional sweet snack firm in Riau Province, Indonesia, was chosen in this case study to test the implementation of PROSEM. The second consideration 
was the product uniqueness through the use of locally sourced raw materials. Aribowo et al. (2018) observed that avoiding imported materials could ensure better business sustainability in Indonesian businesses. The third consideration was driven by the fact that the product has a strong heritage value in the region, making it important that the product thrives in the market.

After selecting the small firm that would be the case study of PROSEM implementation, we could then formulate the research questions and hypotheses based on the partnering SME's real business situation. Based on initial field observation from the firm and an interview with the owner, the study found that the primary problem was the slow revenue growth over the last couple years (Fig. 1).

In business terminology, this phenomenon is called income stagnation, which refers to a business with slow or flat revenue growth (Maryanti et al. 2020). Several macroeconomic factors can cause income stagnation, including competition, policy, taxation, market structure, GDP growth, or demand and supply. Microeconomic drivers include multiple aspects of corporate and consumer behavior. Factors from both areas can influence the SME's business performance (Lopes et al. 2017; Lin and Magnago 2017; Rusu and Roman 2016). One or more of these factors could be the causes of the problem that need further investigation. The potential root causes need to be deconstructed before determining the proper treatments or solutions to overcome the primary problem (Hekkert and Van Dijk 2011). Hence, the study addresses the research questions below:

$R Q 1$ What are the root causes of the income stagnation of the partnering SME?

$R Q 2$ What can possible integrated treatments be given to the partnering SME's identified root causes?

In the end stage of PROSEM, the results must be measured to determine whether the procedure is effective and worth replicating to another real small business situation. Various methods of business assistance, when properly conducted, can improve small businesses' performance (e.g., Formica 2005; Salleh and Omar 2013; D'Este et al. 2019). In an example case, Wren and Storey (2002) conducted an experiment involving two groups, business support treatment and non-treatment business support groups. The result indicated that business support is most effective in the mid-range SMEs who received treatment to increase firm sales turnover and employment rate. Hence, the study hypothesizes:

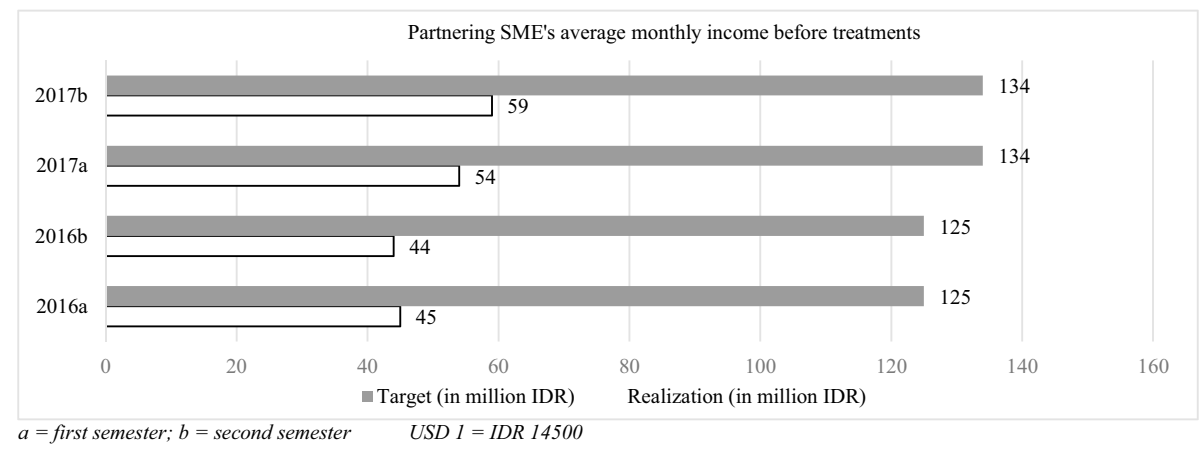

Fig. 1 The average monthly income growth of the SME before treatments 
H1 There is a significant difference in the partnering SME's performance before and after receiving the integrated business treatments.

$H 2$ Effective integrated business treatments significantly improve the partnering SME's business performance.

\section{Method}

The research method followed PROSEM's stages in a single cycle while the analysis was divided into three studies, each of which used a different method (Fig. 2).

A pre-study was initiated, namely, an agreement involving the authors' team and the partnering SME. This arrangement is necessary to develop a mutual understanding of the scope, focus, and project's methods between parties (Lindgren et al. 2004). The first and second studies were conducted to answer research questions ( $R Q 1$ and $R Q 2)$, while the third study aimed to test the hypotheses ( $H 1$ and $H 2)$. A comprehensive mixed-method approach containing qualitative and quantitative methods and action research was tailored to each study's objectives.

\section{Study 1}

The initial PROSEM stages, which started in January 2018 and ended in April 2018, aimed to identify the SME's root problems through an explorative approach and root cause analysis (RCA). The problems were explored using an in-depth interview, a

\begin{tabular}{|c|c|c|c|}
\hline $\begin{array}{l}\text { Pre-study } \\
\text { (Agreement) }\end{array}$ & $\begin{array}{c}\text { Study } 1 \\
\text { (Problem Root Cause) }\end{array}$ & $\begin{array}{c}\text { Study } 2 \\
\text { (Solution Treatments) }\end{array}$ & $\begin{array}{c}\text { Study } 3 \\
\text { (Measurement) }\end{array}$ \\
\hline $\begin{array}{l}\text { MoU between } \\
\text { HEI team and } \\
\text { partnering SME }\end{array}$ & $\begin{array}{l}\text { What are SME's business } \\
\text { problems? }\end{array}$ & $\begin{array}{l}\text { How to overcome those } \\
\text { problems? }\end{array}$ & Are they effective? \\
\hline Target outputs: & $\begin{array}{l}\text { Finding the root causes of } \\
\text { SME's problem }\end{array}$ & $\begin{array}{l}\text { Providing solutions to each } \\
\text { identified cause }\end{array}$ & $\begin{array}{l}\text { Measuring the effectiveness of } \\
\text { treatments }\end{array}$ \\
\hline Activities: & $\begin{array}{l}\text { 1. } \text { Mapping entire } \\
\text { potential problem set; } \\
\text { 2. Finding the root causes; } \\
\text { 3. Selecting feasible and } \\
\text { affordable causes. }\end{array}$ & $\begin{array}{l}\text { 1. Setting action plans; } \\
\text { 2. Conforming the plans with } \\
\text { SME; } \\
\text { 3. Applying the plans; } \\
\text { 4. Involving a third party when } \\
\text { necessary; } \\
\text { 5. Monitoring the processes; } \\
\text { 6. Documenting the processes; } \\
\text { 7. Gathering data. }\end{array}$ & $\begin{array}{l}\text { 1. Testing the datasheet of the } \\
\text { SME's business } \\
\text { performance; } \\
\text { 2. Learning the barriers and } \\
\text { results within the } \\
\text { processes; } \\
\text { 3. Taking any form of } \\
\text { modification, adaptation, or } \\
\text { replacement if necessary. }\end{array}$ \\
\hline Techniques: & $\begin{array}{l}\text { Qualitative approach: } \\
\text { 1. Depth interview; } \\
\text { 2. Root cause analysis. }\end{array}$ & $\begin{array}{l}\text { Action research by determining and } \\
\text { applying practical treatments. }\end{array}$ & $\begin{array}{l}\text { Quantitative approach: } \\
\text { 1. Descriptive analysis; } \\
\text { 2. t-test (pre- and post- } \\
\text { treatments); } \\
\text { 3. General linear model. }\end{array}$ \\
\hline
\end{tabular}

Fig. 2 The practical roadmap of PROSEM 
standard method associated with qualitative studies (Shao 2002). Five to seven semi-structured questions were asked of thirteen interviewees (see Table 1), mainly to address the firm profile, business scale, product variety, quality, production process, and the marketing approach. The entire transcript was selected, analyzed, synthesized, and placed in the result section as the interviewees' indirect and narrative explanations.

After mapping the entire problem, the RCA was performed. The study followed RCA guidance from Mahto and Kumar (2008). The team and interviewees conducted a series of brainstorming sessions to find the root causes. A fault diagram was built, starting with the end failure (income stagnation) and progressively tracing each cause that led to the prior cause. The process continued till the trail could be traced back no further. Only the contributing causes were retained, and all non-contributing causes were removed. Once the fault diagram was completed and checked for logical flow, the team determined the possible effective treatments to prevent the consequences from occurring again.

\section{Study 2}

Study 2, initiated in May 2018 and ended in November 2019, aimed to apply the treatments for each root cause identified. This stage was action research, focused on monitoring and evaluating the impacts of the researcher's direct actions within a participatory community to improve the community's performance quality (McGrath and O'Toole 2012). A practical approach provided treatments for each root cause of the problem identified in Study 1. It is important to note that the treatments were not conducted once but gradually and more than once. The progress was monitored and documented and later used as empirical data (Boldrini et al. 2017) in Study 3. Moreover, using a longitudinal approach makes it possible to understand the effect of the proposed solutions on business performance (Mazzola et al. 2012).

Table 1 Interview Description

\begin{tabular}{llllll}
\hline No & Interviewees & Location & Method & $\begin{array}{l}\text { Duration } \\
\text { (minute) }\end{array}$ & Language \\
\hline 1 & Owner & Workshop & Face-to-face & 46 & Indonesian \\
2 & Production staff-1 & Workshop & Face-to-face & 14 & Indonesian \\
3 & Production staff-2 & Workshop & Face-to-face & 12 & Indonesian \\
4 & Quality Control & Workshop & Face-to-face & 16 & Indonesian \\
5 & Marketing staff & Workshop & Face-to-face & 19 & Indonesian \\
6 & Store-1 & Store & Face-to-face & 25 & Indonesian \\
7 & Store-2 & Store & Face-to-face & 18 & Indonesian \\
8 & Store-3 & Store & Face-to-face & 23 & Indonesian \\
9 & End-consumer-1 & Store & Face-to-face & 4 & Indonesian \\
10 & End-consumer- 2 & Store & Face-to-face & 6 & Indonesian \\
11 & End-consumer-3 & Store & Face-to-face & 6 & Indonesian \\
12 & End-consumer-4 & Store & Face-to-face & 5 & Indonesian \\
13 & End-consumer-5 & Store & Face-to-face & 4 & Indonesian \\
\hline
\end{tabular}




\section{Study 3}

Study 3, which started in December 2019 and finished in January 2020, aimed to measure the treatments' effectiveness in improving the SME's business performance based on its income per month, product volume per month, and product returned rate (as commonly used in Indonesia) (Suliyanto et al. 2017; Bismala 2016). The dummy variables used include before and after treatments, while time-series longitudinal research was employed to gather data from multiple time points (Neuman 2014). Secondary data were collected from two years before and after the assistance was launched. Therefore, the total population was 48 secondary data elements from 48 months of observation. A pretest-posttest experiment (Cooper and Schindler 2011) was conducted to quantitatively evaluate the impacts. An independent t-test analysis was employed to assess the magnitude of the difference in the SME's business achievement before and after the treatment. In addition, a multivariate analysis using the general linear model (GLM) was deployed to test the magnitude of treatment to the dynamic of business turnover, production volume, and product return rate. The results would allow the SME and the HEI teams to decide whether the treatments effectively improved business performance and created new knowledge in the context of the HEI-SME business assistance program.

\section{Results}

\section{Study 1 - Problem Rooting}

A series of in-depth interviews with the firm owner, production staff, marketing, distributors/stores, and end consumers thoroughly overviewed the SME's problems. Each saw the issues from a different perspective, but some could be semantically grouped into the same problem category. Table 2 shows how the interviewees described the fragmented problems.

Basically, the problems were related to each other, and causal relationships were also observed. Therefore, it is necessary to analyze the root cause to determine the real source of the problems. The RCA was conducted to determine appropriate solution treatments. Table 2 also reveals the aspects of working capital and wage, which were excluded from the mind map model due to the limited availability of funding assistance to cover both. The business assistance in this study emphasized knowledge mentoring, technology transfer, and new production methods rather than financial aid.

Figure 3 displays the causal relationships between the issues identified by the interviewees. The first was the income stagnation due to a high product return rate of $20 \%$ to $25 \%$ each month. The returned products were treated as waste because they could not be resold, thereby affecting income. Moreover, the rate also shows the existence of problems in the quality of the finished products. According to the interviews, even though the expiration period should be three months, the product would become hard and unconsumable in the first month. The root cause of the high product return rate is the low durability of the product.

The second predictor of income stagnation was the limited supply to the dealers/stores. Interviews with store owners revealed customer's demand was relatively high, but there was limited availability of products. The circumscribed supply was due to the firm's inability to produce an adequate volume of products demanded by the market. Moreover, 
Table 2 Problem mapping

\begin{tabular}{ll}
\hline Source & Problems \\
\hline Owner & - Working capital \\
& - Income stagnation \\
& - Production volume stagnation \\
& - Lack of human resource \\
& - Local market coverage \\
Production staffs & - Non-ergonomic production layout area \\
& - Inefficient production time \\
& - Wage \\
Marketing staff & - Local market coverage \\
& - High product returned rate \\
& - Wide sales area \\
& - Door-to-door sales method \\
& - High product returned rate \\
Distributors/stores & - Limited supply \\
& - Quality consistency \\
& - Limited flavor \\
End-consumers & - Low durability means the products cannot be \\
& used as souvenirs for people traveling to distant \\
& areas \\
& - Low quality of plastic packaging \\
\end{tabular}

the field observation also revealed inefficiencies in production time such that with a total workforce of only 12 people, the production process was relatively slow. The whole process, ranging from preparation, processing of raw materials, cooking, and packaging, was

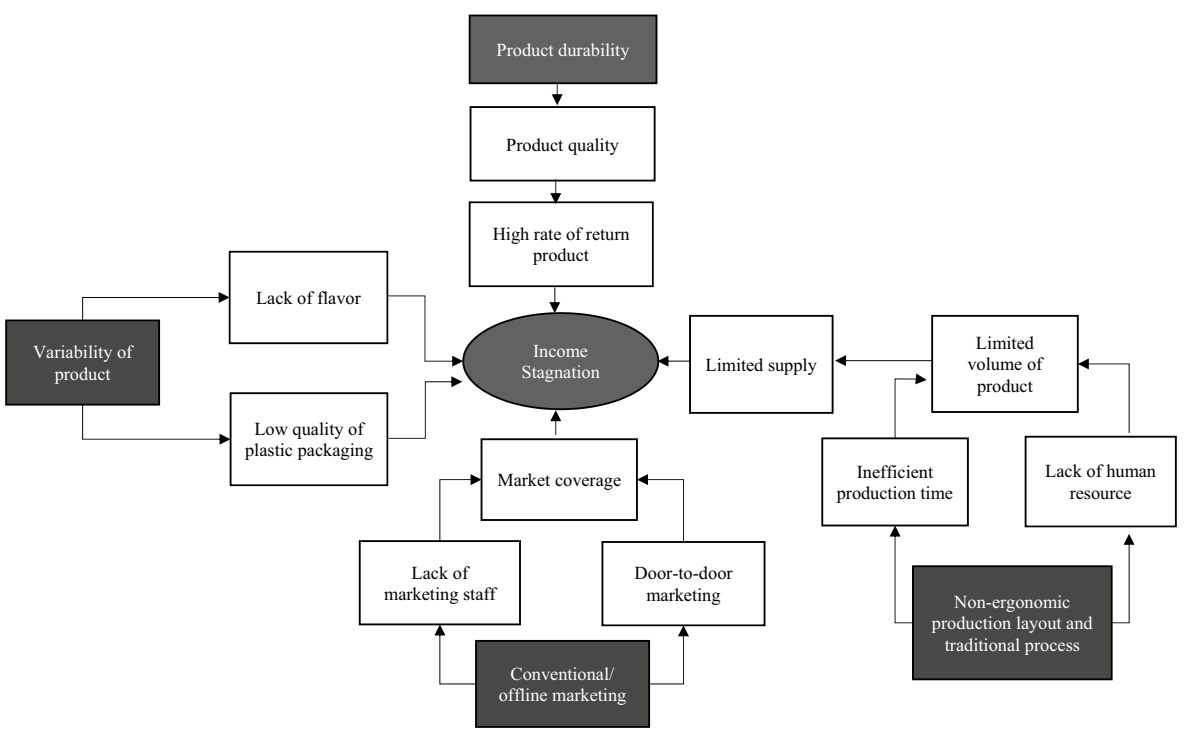

Fig. 3 Problem mind map of observed SME's root causes 
conducted through manual operations. For example, workers could only process $6 \mathrm{~kg}$ of raw materials per day by stirring the dough manually and were observed to be performing overlapping functions due to undefined job descriptions. Furthermore, the plant layout was not well organized, which led to the overlapping of the production and stacking areas. Therefore, the root causes of the second problem include non-ergonomic layout and traditional production processes.

The third was the huge unmet potential of market coverage and the lack of salespeople to market the products using the door-to-door approach. The owner was fully aware of the production volume constraint and decided not to satisfy a potentially greater demand due to the workshop's sub-optimal capacity. The business had no idle capacity that could be optimized to meet the demand. In addition, the marketing strategy was traditional and offline. Therefore, another root cause was the conventional offline marketing process, which led to the inability to reach a wider market area.

Meanwhile, based on the distributors' comments and end consumers, the products were revealed to have a limited variety of flavors. From earlier observation, only four flavors were offered to the market, including pandan, pineapple, purple cassava, and vanilla. The owners acknowledged that these flavors suited the adult segment but were barely consumed by younger consumers. Another complaint was made about the unattractive packaging of the product. Through the use of transparent white plastic with the product brand as the packaging material, it was apparent the firm had not used packaging as a promotional tool. In other words, the packaging was used only to wrap the products. Therefore, the root cause observed from these problems is attached to the variability of the product.

\section{Study 2 - Solution Treatments}

Problem mapping revealed the root causes encountered by the firm included: (1) product durability, (2) non-ergonomic production layout and traditional process, (3) conventional and offline marketing, and (4) product variability. Therefore, the treatments focused on these four aspects. Note that the treatment delivery was based on the application of production technology to minimize financial subsidies (Table 3).

Product Durability The SME's low income was mostly caused by the product becoming hard within a month despite the three-month expiration period. Even though there was no observable change in the product's flavor and edibility, the perceived quality was low. Normally, the hardened products are returned by the stores, recorded as losses, and discarded by the firm. The intervention for this problem was training by a food technology professor to demonstrate appropriate methods of processing foodstuffs. A two-day training was held at the firm's workshop and attended by all production staff. The expert introduced Stabilex $\mathrm{BR}$, a modified starch that binds water in the dough to maintain the softness and increase the finished product's durability.

Non-ergonomic Production Layout and Traditional Process Several inefficient staff movements were observed due to the improper production area, which also led to a long production time. The layout further caused a reduction in production volume and low supply to stores. The solution proposed was to reorganize the layout to fit the production process flow and follow raw material storage dough preparation dough cooking molding inside wrapping outer packaging quality control finished product storing finished product display, as shown in Fig. 4. The workers were divided according to each production 


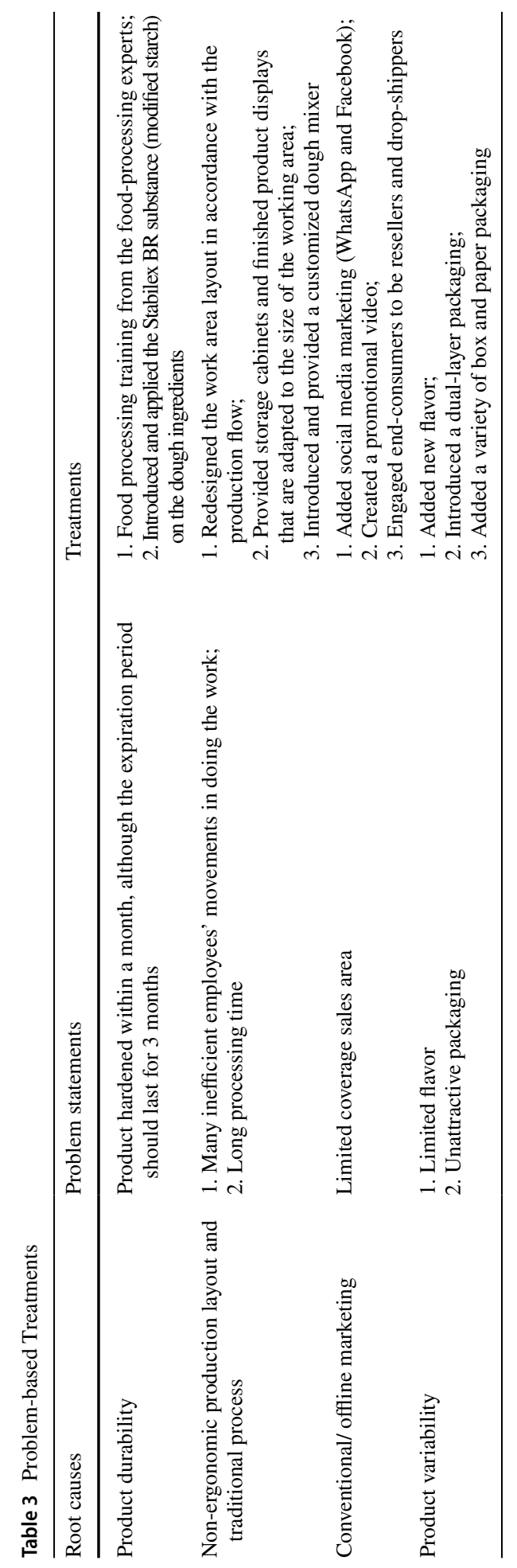



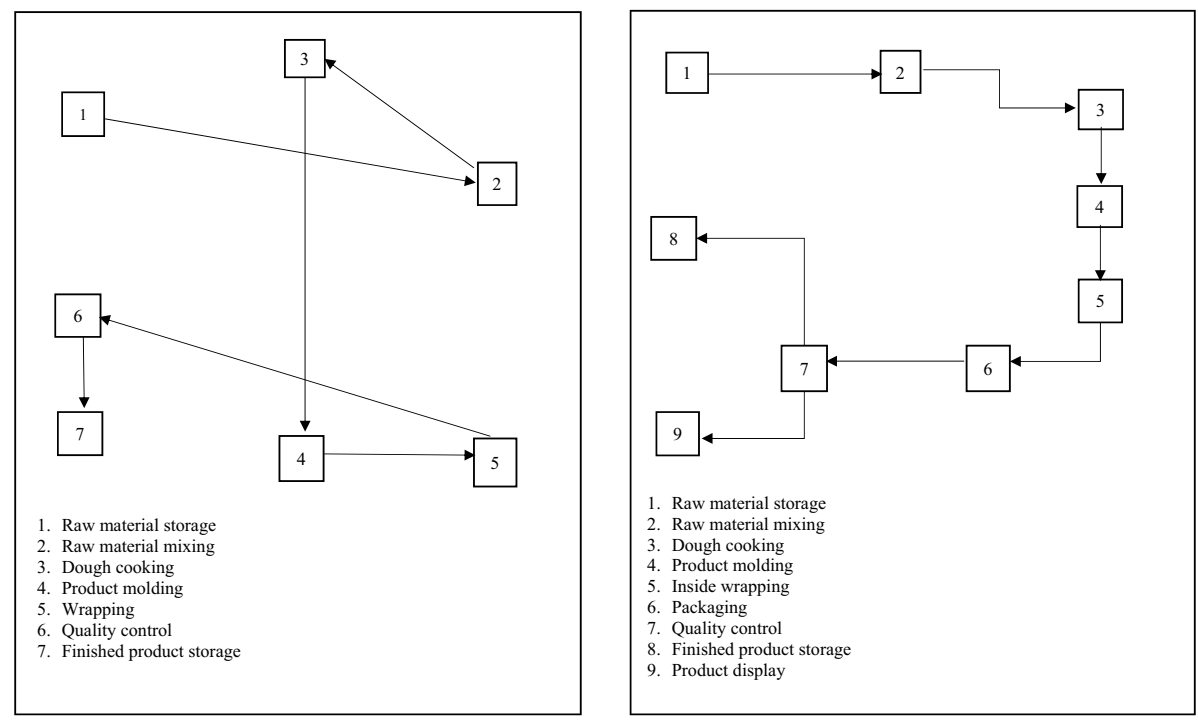

Fig. 4 Working area layout before (left) and after treatment (right)

process. Moreover, storage cabinets and showcases customized according to the needs and space available were provided to ensure the finished product's hygiene and organize tidier storage and display area. A dough mixer tailored to the firm's optimum capacity was also provided to speed the mixing and cooking process.

Conventional/Offline Marketing The limitation on the production volume yield led to traditional marketing, which involved door-to-door store visits. The use of only one marketing person limited the coverage of potential sales territories, and this was one of the factors observed to be causing income stagnation. For these reasons, online marketing was introduced by utilizing social media platforms such as WhatsApp and Facebook. A twominute promotional video was created for these channels. The reseller and drop-shipper methods were used for greater audience coverage, involving consumers in the marketing chain. Resellers buy merchandise from the firm while drop-shippers sell without having to stock the merchandise.

Product Variability Before initiating the treatment, the firm had only four flavors, including pandan, pineapple, purple cassava, and vanilla. Simultaneously, the packaging was also very plain and unattractive, using only transparent white plastic bags with the brand sticker. This problem was solved by introducing a dual-layer packaging method that involved using a thin paper to wrap finished molded products and a paper box to enclose the wrapped products. The product and its information were no longer printed on stickers but directly on the packaging. Moreover, through the guidance from food technology experts, new flavors were launched, including jackfruit and soursop, while strawberry and chocolate were added to diversify the market to the younger segment. 
Table 4 Mean and independent t-test

\begin{tabular}{cclc}
\hline & Income per month (IDR $\left.{ }^{\mathrm{a}}\right)$ & $\begin{array}{l}\text { Production volume per } \\
\text { month (pack) }\end{array}$ & $\begin{array}{l}\text { Returned product } \\
\text { per month (pack) }\end{array}$ \\
\hline $\begin{array}{c}\text { Mean } \\
\text { Before treatment }\end{array}$ & $52,199,334.38$ & $2,292.04$ & 461.21 \\
After treatment & $91,565,625.00^{* * *} \uparrow$ & $3,761.29^{* * *} \uparrow$ & $245.29^{* * *} \downarrow$ \\
$\begin{array}{c}\text { Standard Deviation } \\
\text { Before treatment }\end{array}$ & $5,799,689.95$ & & 48.10 \\
After treatment & $13,528,642.06$ & 235.53 & 133.47 \\
\hline
\end{tabular}

${ }^{\mathrm{a}}$ USD $1=$ IDR 14,500

${ }^{*} \mathrm{p}<0.05,{ }^{* *} \mathrm{p}<0.01,{ }^{* * *} \mathrm{p}<0.001$

$\uparrow$ increase; $\downarrow$ decrease

\section{Study 3}

All the treatments applied in this study were provided to solve the identified root cause problems, with the overall objective of enhancing the firm's business performance. This performance was measured quantitatively to determine the treatments' effectiveness through income generated, production volume, and decrease in the returned product rate.

Table 4 shows all variables of the SME's business performance were significantly improved after the treatment. For example, the income per month was nearly doubled, which means the firm recorded much larger sales. Moreover, the diversification of the marketing model through social media channels and chain marketing expanded the market. The increased production volume was a significant driver of the rising dealer merchandise stocks and increased monthly income. The increment in the merchandise supply also increased the market reach because resellers and drop-shippers have enriched the conventional door-to-door approach.

Furthermore, the technical assistance provided improved the quality of the products and led to a significant reduction of almost half in the number of products returned compared to two years before the treatment. In short, the treatment led to three positive impacts, a drop in the losses, more merchandise supplied, and increased merchandise shelf life.

A multivariate analysis used the GLM to prove the planned and measurable treatment quantitatively improved the partnering SME's business performance. The dependent variables include income, production volume, and returned product per month, while the treatment was used as a dummy variable and predictor, as shown in Table 5. The GLM

Table 5 Multivariate general linear model for treatment towards partnering SME's business performance

\begin{tabular}{lllll}
\hline & F-stat & $\rho$ & Adj. $R^{2}$ & ${ }^{\mathrm{a}} \eta_{p}{ }^{2}$ \\
\hline Treatment $\rightarrow$ Income per month & 171.66 & $0.000^{* * * *}$ & 0.784 & 0.789 \\
Treatment $\rightarrow$ Production volume per month & 189.61 & $0.000^{* * *}$ & 0.801 & 0.805 \\
Treatment $\rightarrow$ returned product per month & 55.59 & $0.000^{* * *}$ & 0.537 & 0.547 \\
\hline
\end{tabular}

a Partial Eta Squared (effect size). Cohen (1988) guideline: $0.02=$ small effect; $0.15=$ medium effect; $0.35=$ large effect.

${ }^{*} \mathrm{p}<0.05,{ }^{* *} \mathrm{p}<0.01,{ }^{* * *} \mathrm{p}<0.001$. 
results showed treatment significantly improved income $\left(F=171.66^{* * *} ; \eta_{p}{ }^{2}=0.789\right)$ and production volume per month $\left(F=189.61^{* * *} ; \eta_{p}{ }^{2}=0.805\right)$, and simultaneously lowered the returned product per month $\left(F=55.59^{* * *} ; \eta_{p}{ }^{2}=0.547\right)$. Entire effects sizes were very strong $\left(\eta_{p}^{2}>0.35\right)$. The treatment's accuracy strongly influenced the increase in income and production volume per month at $78.4 \%$ and $80.1 \%$, respectively, while the returned product per month was $53.7 \%$. These findings proved the HEI's business assistance to the SME, conducted by delivering a well-planned treatment, greatly affected the partnering SME's business performance; thus, the findings supported the two hypotheses.

\section{Discussion}

This study's primary goal was to design effective business assistance from HEI to SME. A PROSEM, constructed by applying the design thinking paradigm, was introduced, implied, and tested in an SME's real business setting to achieve this objective. The goal was then derived into two research questions and two hypotheses, aiming to explore the real causes of the partnering SME's main problem (income stagnation), determine proper treatments and examine the effectiveness of those treatments. Three studies, conducted over a total time of two years, were launched sequentially to investigate the capability of PROSEM to achieve the goal and answer the questions and hypotheses of this research.

In determining the real facing problem by the partnering SME (RQ1), information was gathered comprehensively from the partnering SME owner, staff, clients, and consumers regarding their perceptions about the factors driving the partnering SME's income stagnation. By deploying RCA, the 18 identified problems from all interviewees could then be rooted in four leading causes: product durability, non-ergonomic production layout and traditional process, conventional/offline marketing, and product variability. Obtaining these critical causes - if corrected-could prevent the recurrence of those similar symptoms; thus, to mitigate the problems, one needs first to recognize and comprehend the factors that are causing the problem (Mahto and Kumar 2008). By continuing to ask "why" until the prior cause could be traced back no further, one can retain the contributing causes and discard the non-contributing ones (Chandler 2004; Maryanti et al. 2020). This process can help the HEIs to utilize their resources effectively and efficiently when providing business assistance to their partnering SMEs.

Soon after recognizing the four root causes of the partnering SME's main problem, treatments were carefully planned and designed to answer the RQ2. These treatments involved not only the HEI team (internal solver) but also a collaboration with external professionals such as a food technology expert, a commercial video maker, and a web developer. This study combined the subsidy of work facilities and new production and marketing methods. Both parties, the HEI team and the partnering SME, learned that training on raw material processing and the provision of Stabilex BR substances could increase the product durability, leading to a significant decrease in the product returned rate. Furthermore, the rearrangement of the workspace ergonomics and the provision of a dough mixer created a more efficient process, leading to more finished products to supply to the dealers without adding human resources. Flavor extension and packaging improvement increased income per month due to expanding the consumer segment and increased customer satisfaction. In addition, modernizing marketing methods through social media and leveraging resellers and drop-shippers' role increased sales turnover and expanded the marketing network. These positive results reinforce the study of Rakićević et al. (2016), which suggests 
that better outcomes would be achieved by SMEs that use customized support, rather than adjusting their needs to the help that the HEI team possesses and wants to provide. Such action could cause the SMEs' problems to not be accurately covered and mitigated by the business assistance program. Moreover, each SME has unique characteristics and conditions (Temtime et al. 2004), leading to a requirement for adjusting the specific action framework to the particular SME context (Ismail et al. 2011).

For those reasons, it is essential to make sure that the treatments are need-based and organized to correspond to the SMEs' specific problems, expectations, and requirements (Chrisman and McMullan 2004). The outcomes should be further tested quantitatively to validate the results and strengthen the program's efficacy (e.g., Posavac 2016; Gonera and Pabst 2019). In this case, the quantitative increase (or decrease) of the SME's business performance and its relationship could be the appropriate success support indicators (Rakićević et al. 2016). As such, this study confirms that the evaluation phase is an integral part of many kinds of the action-based problem-solving framework-including the PROSEM-and should be positioned after the solutions or treatments implementation (e.g., Susman and Evered 1978; Davison et al. 2004; Ismail et al. 2011; Stal and PaliwodaPękosz 2019). Correspondingly, based on the hypotheses testing results, this study clearly showed that HEI's business assistance has a precise and measurable influence on increasing the partnering SME's business performance. There were significant differences in partnering SME's monthly income (increase), production volume (increase), and returned product volume (decrease) caused by the series of treatments provided. The improvement included enhancing SME income, which was the main reason for this study (Fig. 5). Such findings are thus in line with other previous studies highlighting the importance of well-planned and customized business supports for improving SMEs' business performance (e.g., Chrisman and McMullan 2004; Temtime et al. 2004; Ferreira et al. 2010; Rakićević et al. 2016).

Returning to this study's main goal to design effective HEI-to-SME business assistance, we contend that the program should be initiated by recognizing the partnering SME's actual needs before determining the proper treatments to mitigate specific problems of the SME. This step is vital to avoid any mismatch between HEIs' and SMEs' interests (Storey 2002; Lövsund et al. 2020). The processes and data collection should be documented at each step-before and after the treatment-so they can be analyzed and evaluated in

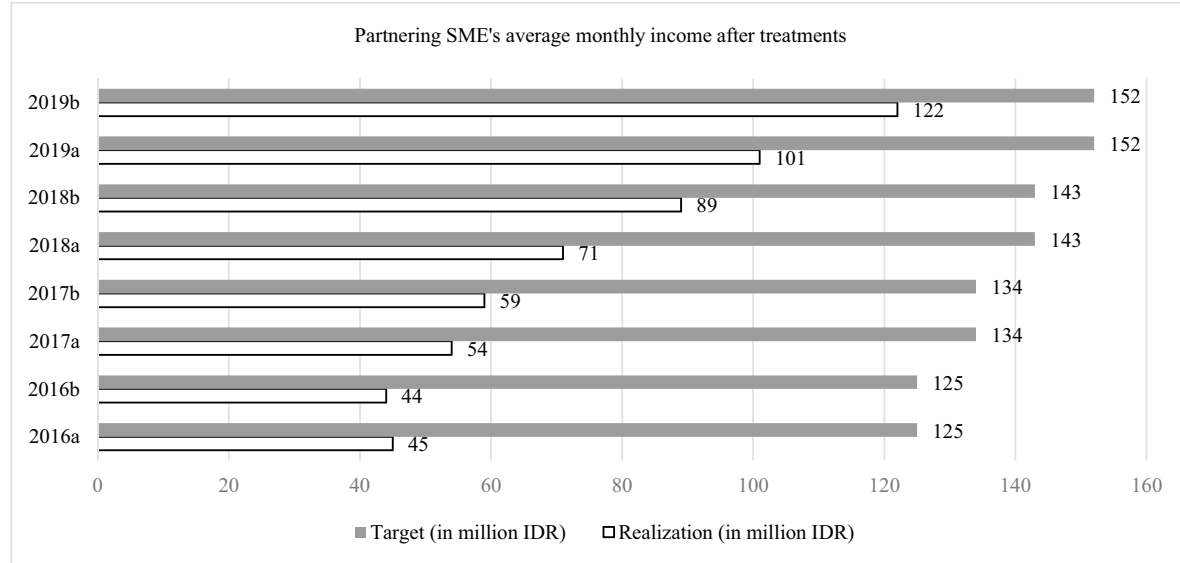

Fig. 5 The average monthly income growth of the partnering SME after treatments 
the end. The measurement results then can be a valuable lesson learned by both parties to decide whether or not the program helped to boost the SME's performance, and at the same time, can satisfy the HEI's interests of academic fulfillment. Evaluating the value of an engagement allows the HEI to utilize their resources efficiently to deepen and apply knowledge in the industry and solve their partnering SMEs' problems effectively.

\section{Contributions}

\section{Theoretical Contribution}

Extensive past literature concerning HEI-SME business support has focused more on evaluating or assessing the effectiveness of the support types that were delivered; the results relatively vary, confirming that each SME has different conditions and thus needs different treatment (Temtime et al. 2004; Rakićević et al. 2016; Maryanti et al. 2020). However, how to design and install a useful program has been overlooked and remains unclear, thereby leaving huge concerns about the mismatch between HEIs' and SMEs' interests. This possible mismatch often fails to satisfy both parties, and, unfortunately, SMEs are usually the more dissatisfied party (e.g., Storey 2002; Ferreira et al. 2010; Ismail et al. 2011; Bjursell and Engstrom 2017; Lövsund et al. 2020). As such, this paper might contribute to narrowing the gap in the literature concerning this matter.

This study's main contribution lies in the insights gained from how the design thinking paradigm is embedded in the development of effective HEI-SME business assistance. In this paper, support is manifested in the PROSEM procedure: how it should be applied in a real small business setting, what impacts could be achieved, and what kind of lessons could be learned by the HEI and the SME. The effectiveness of PROSEM can also broaden and support previous studies whose results prove the benefit of using design thinking in action research in many areas and specific situations (e.g., Liedtka 2011; Wetzler 2013; Selloni and Corubolo 2017; Che-Tu et al. 2018), particularly in an industry-academia context (e.g., Gonera and Pabst 2019). At the same time, PROSEM might become one alternative among other evolving action research models such as CAR, Soft System, ETHICS, and so forth (please see Davison et al. 2004) that can be adjusted to specific circumstances in various disciplines.

\section{Practical Contribution}

De Faoite et al. (2004) state that the business support offered by HEIs to SMEs is mostly not very effective in practice, resulting in a high failure rate of implementing such programs throughout the world (Ferreira et al. 2010). Lack of replicable and practical HEISME collaboration guidelines could lead to some difficulties in getting the programs executed successfully in the long term (Thune 2007). Hence, for the HEIs' practitioners, the PROSEM procedure, whose effectiveness has been tested in this study, could be an alternative guideline for planning, executing, and evaluating a business assistance program to SMEs. This study shows that the importance of applying RCA in rooting the SME's problems - derived from multiperspective information sources-emphasizes the necessity of deconstructing the problem before determining and initiating specific and straightforward treatments or solutions (Dorst 2011; Hekkert and Van Dijk 2011) to meet the particular need of the SME. The treatments offered and applied in this study encourage business 
assistance practitioners to involve external support from professionals because some issues could not be solved by the HEI team alone.

Both Payne and Wenger (1998) and Wang and Chiew (2010) show the possibility that business assistance practitioners may not be able to find a solution on their own; thus, they need external help. This strategy is much better than simply ignoring the problem and forcing the partnering SME to accept only the solution that the HEI team can offer. The ignored problem might be the most crucial issue for the SME, and the solution being offered could be, perhaps, not needed by the SME. Lastly, although the result measurement occurs after implementing the treatments, strengthening Sari et al.'s suggestion (2019), the progress and data collection should be carried out and documented at each step. The pre-and posttreatment database must be tested quantitatively to increase the treatments' effectiveness.

An HEI's business assistance program can be beneficial for a SME's business development. As Lewis et al. (2007) said, in many parts of the world, there is a gap in the knowledge base perceived by the SME owner-managers in their interaction with a business assistance program, and this gap might lead to their skepticism toward the HEI team. Moreover, it is commonly understood that HEIs focus on developing the body of knowledge theoretically, while SMEs tend to capitalize on the applied or practical knowledge to improve their business process (e.g., Bjursell and Engstrom 2017). Consequently, the HEI's business assistance may be perceived as somewhat irrelevant, inappropriate, and impractical (Johnson and Tilley 1999; Ferreira et al. 2010). The pre-stage of the PROSEM procedure requires a mutual agreement from both HEI and SME to explore and find the core problems jointly and plan and decide what kind of treatment would be implemented. This method could also open a wider opportunity for knowledge exchange between both parties. Thus, as stated by Flood (2000), this combination might put researchers (HEIs) and practitioners (SMEs) into one joint team to find the best treatment together, which, in turn, could boost the SME's performance. The improvement will then provide a multiplier effect by expanding employment opportunities and improving the surrounding communities' economic welfare.

It is also worth highlighting that the PROSEM procedure would be best implemented with a small number of local SMEs (this study only used one small local firm, given the limited resources the HEI team possessed) to achieve better effectiveness. This strategy is in line with Peças and Henriques's (2006) suggestion that university-industry collaboration should be formed in a small project and localized to ensure its strong and long-term relationship. Small projects make it easier to define each party's role, achieve higher personal trust, communicate in an interpersonal manner rather than a formal one, and maintain the program intensiveness and sustainability (Demain 2001; Wahyudi 2009). In vein with Mole et al. (2011), a "deeper" strategy, focusing and intensifying more resources to a small proportion of SMEs, would give a better result than a "broader" strategy that spreads thin resources to a broader range of recipient SMEs.

\section{Limitations}

The first limitation of this research is that this study was conducted on only one small firm in Indonesia. Thus, the worldwide generalizability of the results could be somewhat debatable. However, we could argue that the situation encountered in this HEI-SME collaboration is similar to other HEI-SME engagements in many parts of the world. That is, knowledge and interest gaps on both parties could result in the ineffectiveness of the 
business assistance provided (e.g., Lewis et al. 2007; Ferreira et al. 2010; Virani 2014; Lövsund et al. 2020). Most HEIs fail to understand SMEs' real problems and needs. To tackle this global issue, PROSEM anticipates such potential conflict by requiring the HEI and the SME to sit together as equal partners, creating a joint written agreement before initiating the program to explore the root causes and determine the treatments together. This strategy is universally replicable because, instead of initially dictating the specific treatments, which could vary in different situations, PROSEM emphasizes the importance of the prior processes before determining the treatments. Moreover, the RCA technique embedded in our PROSEM procedure is also a common strategy worldwide. Therefore, we believe that the procedure could serve as practical guidance in many different businesses and countries.

Another limitation might be that although our partnering SME's monthly average income has increased significantly within the two-year assistance program period, the outcome did not entirely meet the average targeted income until the end of the program (Fig. 5). Furthermore, after the program ended, quite satisfactorily, in January 2020, our partnering SME informed us that their income dramatically decreased by $30 \%$ from April to October 2020. The income drop within that period cannot be separated from the fact that many consumers lost their purchasing power caused by the global economic recession during the COVID-19 pandemic. Therefore, in line with Davison et al. (2004), although a single cycle of action research might work effectively, additional cycles might be necessary to perfect our project, particularly to further investigate the recent income drop and then gain a useful reflection about business strategies to apply during the crisis.

Furthermore, our eleven treatments (Table 3) were applied simultaneously to overcome four identified root causes due to the treatment methodology carried out in this study. The simultaneous application of whole treatments causes difficulty identifying which one is most effective. For future studies, when the program requires more than one treatment type, we suggest separating different treatment(s), in different period(s) if possible, where each one is conducted and evaluated as a sub-cycle within one big cycle of action research, to gain a clear picture of each treatment's effectiveness.

\section{Conclusion}

This paper contributes to narrowing the gap between the HEI's and SME's interests, and at the same time, to filing the dearth of practical guidance in conducting an HEI-SME collaboration. In doing so, our PROSEM procedure - as an alternative model modified from the DT concept-could answer the main goal of this study and all the research questions and hypotheses. That is, to conduct effective HEI-SME business assistance, the DT paradigm could guide both parties to deconstructing the leading causes of the problem, determining the possible and feasible treatments, and measuring its effectiveness properly. Thus, we could be assured that DT is an open and adjustable concept of the problem-solving method that can be modified and applied universally in various situations, areas, and disciplines. In our case, slight adjustments such as requiring a mutual understanding from both parties, involving multiple stakeholders when mapping the problems, collaborating with external supports, and quantitatively measuring the outcomes could dramatically increase its effectiveness without substantially changing the essence of the DT procedure. 


\section{References}

Adham KA, Muhammad NS, Said MF, Sarhadat SA, Ismail HA, Nasir MFAM (2019) Diagnosing business incubation for social purpose: a viable system approach. Syst Pract Action Res 32:219-238. https://doi. org/10.1007/s11213-018-9465-8

Ankrah S, Al-Tabbaa O (2015) Universities-industry collaboration: a systematic review. Scand J Manag 31:387-408. https://doi.org/10.1016/j.scaman.2015.02.003

Aribowo H, Iswati, Putra YD (2018) Kiat dan strategi perguruan tinggi dalam pemberdayaan potensi Usaha Mikro Kecil Menengah (UMKM) daerah dalam rangka meningkatkan daya saing perekonomian daerah sebagai bagian dari Tri Dharma perguruan tinggi [Tips and strategy for higher education institution in empowering the potential of local SMEs to enhance the regional economic competitiveness as part of "Tri Dharma" in the higher education institution]. Paper presented at the Annual Conference on Community Engagement, Hotel Swiss-Bellin Airport, 26 - 28 October 2018, Surabaya, Indonesia

Bismala L (2016) Model manajemen Usaha Mikro Kecil dan Menengah (UMKM) untuk meningkatkan efektivitas usaha kecil menengah [The management model for small- and medium-sized enterprises (SME) to enhance the effectiveness of small-medium firms]. J Entrepreneur Entrep 5(1):19-26

Bjursell C, Engstrom A (2017) A Lewinian approach to managing barriers to university-industry collaboration. High Educ Pol 32:129-148. https://doi.org/10.1057/s41307-017-0074-4

Boldrini JC, Caverot G, Ezequel M (2017) The journey in open innovation to develop a SME: a longitudinal case study in a French robotics company. https://halshs.archives-ouvertes.fr/halshs-01502720. Accessed 20 Nov 2019

Boruch RF (1997) Randomized experiments for planning and evaluation: a practical guide. Sage, Thousand Oaks

Breen J, Seers SB (2002) The small business assistance dilemma: is the disparity between the offerings of support agencies and the needs of businesses irreconcilable. Small Enterp Res 10(1):49-58. https://doi. org/10.5172/ser. 10.1 .49

Buzan T (1995) The mind map book, 2nd edn. BBC Books, London

Calgren L, Elmquist M, Rauth I (2016) Exploring the use of design thinking in large organizations: towards a research agenda. Swed Des Res J 11(1): 55-63. https://svid.ep.liu.se/article/view/523. Accessed 11 Nov 2020

Chandler F (2004) Using root cause analysis to understand failures and accident. Material presented in 7 th Military and Aerospace Programmable Logic Devices (MAPLD) September 8, 2004. Available at https://www.slideserve.com/Patman/using-root-cause-analysis-to-understand-failures-accidents. Accessed 9 Jan 2021

Che-Tu J, Xia-Li L, Yi-Wu K (2018) Study on the learning effectiveness of Stanford design thinking in integrated design education. Sustainability 10(8):2649. https://doi.org/10.3390/su10082649

Chrisman JJ, McMullan EW (2004) Outsider assistance as a knowledge resource for new venture survival. J Small Bus Manage 42(3):229-244. https://doi.org/10.1111/j.1540-627X.2004.00109.x

Cohen J (1988) Statistical power analysis for the behavioral sciences, 2nd edn. Erlbaum, Hillsdale

Cooper DR, Schindler PS (2011) Business research methods, 12th edn. McGraw-Hill Irwin, New York

Davies A (2004) Moving base into high-value integrated solutions: a value stream approach. Ind Corp Chang 13(5):727-756. https://doi.org/10.1093/icc/dth029

Davison RM, Martinsons MG, Kock N (2004) Principles of canonical action research. Inform Syst J 14(1):65-86. https://doi.org/10.1111/j.1365-2575.2004.00162.x

D'Este P, Llopis O, Rentocchini F, Yegros A (2019) The relationship between interdisciplinary and distinct modes of university-industry interaction. Res Policy 48(9):1-23. https://doi.org/10.1016/j.respol.2019. 05.008

De Faoite D, Henry C, Johnston K, Van Der Sijde P (2004) Entrepreneurs' attitudes to training and support initiatives: evidence from Ireland and the Netherlands. J Small Bus Enterp Dev 11(4):440-448. https:// doi.org/10.1108/14626000410567080

Demain AL (2001) The relationship between universities and industry: the American university perspective. Food Technol Biotechnol 39(3):157-160

Dorst K (2011) The core of 'design thinking' and its application. Des Stud 32(6):521-532. https://doi.org/ 10.1016/j.destud.2011.07.006

Eppler MJ (2006) A comparison between concept maps, mind maps, conceptual diagrams, and visual metaphors as complementary tools for knowledge construction and sharing. Inf Vis 5(3):202-210. https:// doi.org/10.1057/palgrave.ivs.9500131

Fang N, Yuli Z, Hongzhi X (2009) Acquistion of resources, formal organization and entrepreneurial orientation new ventures. JCE 1(1):40-52. https://doi.org/10.1108/17561390910916877 
Fausiah S (2016) Efektivitas pembinaan usaha industri kecil olahan pangan oleh Dinas Koperasi UMKM Perindustrian dan Perdagangan Kabupaten Sigi (Studi di Kecamatan Sigi Biromaru) [The effectiveness of small food business assistance by the Cooperative, SME, Industry, and Trade Department in Sigi District (Study in sub-district of Sigi Biromaru)]. E-J Katalogis 4(1):68-81

Ferreira E, Strydom J, Nieuwenhuizen C (2010) The process of business assistance to small and medium enterprises in South Africa: preliminary findings. J Contemp Manag 7(1):94-109

Flood RL (2000) A brief review of Peter B. Checkland's contribution to systemic thinking. Syst Pract Action Res 13(6):723-731. https://doi.org/10.1023/A:1026423411383

Formica P (2005) Knowledge transfer from universities to the SME sector. J Educ Technol 2(2): 49-59. https://eric.ed.gov/?id=EJ1068837. Accessed 20 Nov 2019

Gibb A (2000) SME policy, academic research and the growth of ignorance, mythical concepts, myths, assumptions, rituals and confusions. Int Small Bus J 18(3):13-55. https://doi.org/10.1177/0266242600 183001

Gonera A, Pabst R (2019) The use of design thinking in transdisciplinary research and innovation consortia: challenges, enabler and benefits. J Innov Manag 7(3):96-122. https://doi.org/10.24840/2183-0606_ 007.003_0006

Gordon I, Hamilton E, Jack S (2012) A study of a university-led entrepreneurship education programme for small business owner/managers. Entrep Reg Dev Int J 24(9-10):767-805. https://doi.org/10.1080/ 08985626.2011.566377

Grimm M, Paffhausen AL (2015) Do intervensions targeted at micro-entrepreneurs and small and mediumsized firms create jobs? A systematic review of the evidence for low and middle income countries. Labour Econ 32:67-85. https://doi.org/10.1016/j.labeco.2015.01.003

Johnson D, Tilley F (1999) HEI and SME linkages: recommendations for the future. Int Small Bus J 17(4):66-81. https://doi.org/10.1177/0266242699174004

Hekkert P, Van Dijk MB (2011) Vision in Design: a guidebook for innovators. BIS Publishers, Amsterdam

Hong L, Lu J (2016) Assessing the effectiveness of business incubators in fostering SMEs: evidence from China. Int J Entrep Innov Manag 20(1-2):45-60. https://doi.org/10.1504/IJEIM.2016.075298

Ismail HS, Polton J, Sharifi H (2011) An interventionist framework for promoting sustainable growth in SMEs: the role of HEIs as implementation specialist. Eviron Plann C Gov Policy 29:622-640. https:// doi.org/10.1068/c1003b

Jones O, Macpherson A, Thorpe R (2010) Learning in owner-managed small firms: mediating artefacts and strategic space. Entrep Reg Dev 22(7-8):649-673. https://doi.org/10.1080/08985620903171368

Lambrecht J, Pirnay F (2005) An evaluation of public support measures for private external consultancies to SMEs in the Wallon region of Belgium. Entrep Reg Dev 17:89-108. https://doi.org/10.1080/08985 62042000338598

Lewis K, Massey C, Ashby M, Coetzer A, Harris C (2007) Business assistance for SMEs: New Zealand owner-managers make their assessment. J Small Bus Enterp Dev 14(4):561-566. https://doi.org/10. $1108 / 14626000710832695$

Liedtka J (2011) Learning to use design thinking tools for successful innovation. Strateg Leadersh 39(5):1319. https://doi.org/10.1108/10878571111161480

Lin J, Magnago FH (2017) Electricity markets: theories and applications. Wiley, Somerset

Lindgren R, Henfridsson O, Schultze U (2004) Design principles for competence management systems: a synthesis of an action research study. MIS Q 28(3): 435-472. http://www.jstor.org/stable/25148646. Accessed 11 Nov 2019

Lopes C, Hamdok A, Elhiraik, A (2017) Macro-economic policy and pathways to structural trans-formation of African Economics. In: Lopes C, Hamdok A, Elhiraika A Macroeconomic Policy Framework for Africa's Structural Transformation. Palgrave Macmillan, Cham, pp 263-280

Lövsund P, Hillemyr A, Krikis N (2020) Enhance interaction between HEIs and SMEs to stimulate research and innovation. University-Industry Interaction Online Conference. https://research.chalmers.se. Accessed 9 Jan 2021

Mahto D, Kumar A (2008) Application of root cause analysis in improvement of product quality and productivity. J Ind Eng Manag 1(2): 16-53. http://hdl.handle.net/10419/188371. Accessed 18 Nov 2019

Martin R (2009) The design of business. Harvard Business Press, Cambridge

Maryanti S, Suci A, Sudiar N, Hardi (2020) Root cause analysis for conducting university community service to micro and small firms. J Manajemen Kewirausahaan 22(2):152-160. https://doi.org/10.9744/ jmk.22.2.152-160

Matt DT, Rauch E (2013) Implementation on lean production in small sized enterprises. Procedia CIRP 12:420-425. https://doi.org/10.1016/j.procir.2013.09.072

Mazzola E, Bruccoleri M, Perrone G (2012) The effect of inbound, outbound and coupled innovation on performance. Int J Innov 16(6):1-27. https://doi.org/10.1142/S1363919612400087 
McGrath H, O'Toole T (2012) Critical issues in research design in action research in an SME development context. Eur J Train Dev 36(5):508-526. https://doi.org/10.1108/03090591211232075b

Mole KF, Hart M, Roper S, Saal DS (2011) Broader or deeper? Exploring the most effective interventional profile for public small business support. Environ Plan A 43:87-105. https://doi.org/10.1068/a43268

Neuman WL (2014) Social research methods: qualitative and quantitative approaches, Pearson new, international. Pearson Education Limited, Essex

Noor IHM (2010) Penelitian dan pengabdian masyarakat pada perguruan tinggi [Research and the community service of higher education institutions]. J Pendidikan Kebudayaan 16(3):285-297

Payne DG, Wenger MJ (1998) Cognitive psychology. Houghton Mifflin Company, Boston

Peças P, Henriques E (2006) Best practices of collaboration between university and industrial SMEs. Benchmark Int J 13(1/2):54-67. https://doi.org/10.1108/14635770610644574

Peña I (2004) Business incubation centers and new firm growth in the Basque country. Small Bus Econ 22(3-4):223-236. https://doi.org/10.1023/B:SBEJ.0000022221.03667.82

Perkmann M, Neely A, Walsh K (2011) How should firm evaluate success in university-industry alliances? A performance measurement system. R\&D Manag 41(2):202-216. https://doi.org/10.1111/j.14679310.2011.00637.x

Polya G (1954) Patterns of plausible inference. Princeton University Press, Princeton

Posavac EJ (2016) Program evaluation: methods and case studies. Routledge, New York

Puukka J (2008) Higher education institutions and regional mission: lesson learnt from the OECD review project. High Educ Pol 21:217-244. https://doi.org/10.1057/hep.2008.7

Rakićević Z, Omerbegović-Bijelović J, Lěcić-Cvetković D (2016) A model of effective planning of SME support services. Eval Program Plann 54:30-40. https://doi.org/10.1016/j.evalprogplan.2015.09.004

Rezk SS, Gamal S (2020) An organizational cybernetics framework for designing a viable higher education system. Syst Pract Action Res 33:703-724. https://doi.org/10.1007/s11213-019-09505-9

Rowe P (1987) Design thinking. MIT Press, Cambridge

Rusu VD, Roman A (2016) The impact of macroeconomic conditions on SMES performance in terms of employment. Rev Econ 68(3):142-159

Salleh MS, Omar MZ (2013) University-industry collaboration models in Malaysia. Procedia - Soc Behav Sci 102:654-664. https://doi.org/10.1016/j.sbspro.2013.10.784

Sari YP, Farida I, Hetika (2019) Model pendampingan UMKM pengolahan hasil laut dengan metode pendekatan pendampingan terintegrasi [The assistance model for sea product processing SMEs using the integrated assistance approach]. J Monex 8(1):293-302. https://doi.org/10.30591/monex.v8i1.1269

Selloni D, Corubolo M (2017) Design for social enterprises: how design thinking can support social innovation within social enterprises. Des J 20(6):775-794. https://doi.org/10.1080/14606925.2017.1372931

Shao AT (2002) Marketing research: an aid to decision making, 2nd edn. South-Western-Thomson Learning, Ohio

Stacey R, Griffin D, Shaw P (2000) Complexity and management: fad or radical challenge to system thinking? Routledge, London

Stal J, Paliwoda-Pękosz G (2019) Fostering development of soft skills in ICT curricula: a case of a transition economy. Inf Technol Dev 25(2):250-274. https://doi.org/10.1080/02681102.2018.1454879

Storey D (2002) Methods of evaluating the impact of public policies to support small business: the six steps to heaven. Int J Entrep Educ 1(2):181-202

Suliyanto, Novandari W, Mustaufik (2017) Dampak program IbPEbagi UKM gula kelapa di Kabupaten Banyumas Provinsi Jawa Tengah [The effect of IbPE program on coconut sugar SMEs in the district of Banyumas in Central Java Province]. J Manajemen Bisnis Media Ekonomi 17(1):1-6

Susman GL, Evered RD (1978) An assessment of the scientific merits of action research. Adm Sci Q 23:582-603. https://doi.org/10.2307/2392581

Tambunan T (2007) Entrepreneurship development: SMEs in Indonesia. J Dev Entrep 12(1):95-118. https:// doi.org/10.1142/S1084946707000575

Tambunan T (2008) SME development, economic growth, and government intervention in a developing country: the Indonesian story. J Int Entrep 6:147-167. https://doi.org/10.1007/s10843-008-0025-7

Temtime ZT, Chinyoka SV, Shunda JPW (2004) A decision tree approach for integrating small business assistance schemes. J Manag Dev 23(6):563-578. https://doi.org/10.1108/02621710410541132

Thorpe R, Cope J, Ram M, Pedler M (2009) Leadership development in small-and medium-sized enterprises: the case for action learning. Action Learn Res Pract 6(3):201-208. https://doi.org/10.1080/ 14767330903299399

Thune T (2007) University-industry of collaboration: the network embeddedness approach. Sci Public Policy 34(3):158-168. https://doi.org/10.3152/030234207X206902 
Virani TE (2014) Mechanism of collaboration between creative small, medium and micro-sized enterprises and higher education institutions: reflection on the creativeworks london creative voucher scheme. Paper No. 4, Queen Mary, University of London

Wade A, Demb A (2009) A conceptual model to explore faculty community engagement. Mich J Community Serv Learn 15(2): 5-16. https://eric.ed.gov/?id=EJ859461. Accessed 20 Nov 2019

Wahyudi I (2009) Program pendampingan terintegrasi alternatif solusi kendala non-modal bagi UKM [The integrated assistance program as the alternative solution for SMEs non-financial barriers]. https://iyuk. wordpress.com/2009/04/11/program-pendampingan-ukm-terintegrasi/. Accessed 18 Nov 2019

Wang Y, Chiew V (2010) On the cognitive process of human problem solving. Cogn Syst Res 11(1):81-92. https://doi.org/10.1016/j.cogsys.2008.08.003

Warren L (2003) Toward critical intervention is small-and medium sized enterprises: a case study. Syst Pract Action Res 16(3):197-211. https://doi.org/10.1023/A:1023859805741

Wetzler JR (2013) A case study of a "Collaborative Organizational Innovation" intervention, combisning action research and design thinking Methodologies. ProQuest LLC. https://eric.ed.gov/?id=ED554 293. Accessed 11 Nov 2020

Wilson PF, Dell LD, Anderson GF (1993) Root cause analysis: a tool for total quality management. Quality Press, Milwaukee

Wren C, Storey DJ (2002) Evaluating the effect of soft business support upon small firm performance. Oxf Univ Pap 54:334-365. https://doi.org/10.1093/oep/54.2.334

Publisher's Note Springer Nature remains neutral with regard to jurisdictional claims in published maps and institutional affiliations. 